FACTA UNIVERSITATIS

Series: Linguistics and Literature Vol. 18, No 1, 2020, pp. 37-51

https://doi.org/10.22190/FULL2001037M

Review Paper

\title{
GRAMMAR OF THE DETECTIVE GENRE
}

\author{
UDC 82.09-312.4
}

\section{Dejan D. Milutinović}

University of Niš, Faculty of Philosophy, Serbian Department, Niš, Serbia

\begin{abstract}
The paper describes the grammar of the detective genre. This is done on the basis of formalist-structuralist poetics, by extracting the actants of detective syntax. It involves: the plot, enigma, secret, solution, crime, and the detective. The plot is determined both on the basis of the main stages of the detective narrative (crime, investigation, explanation) and depending on the reader's reading experience. An enigma is the absence of information about someone/something, but it is also part of the plot - it hides events which led to a specific crime. The secret is connected with the enigma and concerns both the crime and the detective. The solution is considered by many to be the most important feature of the detective genre, which has a distinctly ideological character. A crime is a motive, not a goal - it happens outside the text, and is transmitted through the text. The detective is a distinctive figure of this genre, determined by intellectual and scientific abilities, but also by eccentricity and fragmentation.
\end{abstract}

Key words: plot, enigma, secret, solution, crime, detective

\section{INTRODUCTION}

There are different ways of studying each genre, i.e. a variety of aspects can be the focus of research. They all fall into four categories: a) syntactic, which deals with the formalistic sides of the genre, b) semantic, which emphasizes its meaning, c) pragmatic, which considers the position of the genre within discourse practices, and d) cognitive, which studies the relations between genre and cognition. ${ }^{1}$

It can be observed that most traditional poetics is predominantly based on the syntactic approach. This is understandable because only with a defined syntax of the genre can one speak of its other characteristics: cognitive, semantic, and pragmatic. Therefore, in this paper we will deal with the syntax, that is, the grammar of the detective

Submitted May 5, 2020; Accepted May 31, 2020

Corresponding author: Dejan Milutinović

University of Niš, Faculty of Philosophy

E-mail: dejan.milutinovic@ filfak.ni.ac.rs

${ }^{1}$ This is an analytical systematization since in the poetics of the genre there is mutual interaction between (almost) all these aspects. 
genre. By emphasizing the notion of grammar, we emphasize that it is the poetics of formalists and structuralists who considered each detective story to be a part of the larger abstract structure and took as their primary task the description of that structure in an effort to arrive at the grammar of the detective narrative. The "main character" of the study is the plot (story) which is singled out as suitable for explicating general principles by which narratives operate.

Such studies date back from the 1930s when significant works in French appeared over the span of three decades: François Fosca, Historie et Technique du Roman Policier, Paris, 1937; Roger Caillois, Le Roman policier, Paris, 1941; Thomas Narcejac, Esthétique du roman policier, Paris, 1947; Fereydoun Hoveyda, Petite Histoire du roman policier, Paris, 1956; Boileau-Narcejac, Le roman policier, Paris, 1964. The basis of the formaliststructuralist study of the detective genre can be found in papers written by Viktor Shklovsky and Tzvetan Todorov.

Shklovsky's work “Новелла тайн” appeared in 1929 (Шкловский 1929, 125-142). Starting from Conan Doyle's story, Shklovsky analyzes the construction of the detective novella. He considers the basic problem to be the possibility of "drawing two lines normal to one line" from one point, which implies that the primary characteristics of this type of novel are related to the necessity of logically uniting seemingly unrelated things. In his description, Shklovsky uses the names “сыщицкие рассказы”, “сыщицкий роман" because the term detective was not in use at that time in Russia.

Shklovsky (Шкловский 1929, 125-142) assumes that all narratives can be presented in two ways. The first is a chronological one, when an action causally unfolds before the eyes of the reader without significant disturbances in temporal continuity. In the second, the events are unknown, the story is based on a mystery and its closure; in this case, a time clip, that is, an event left out and described after it has taken place serves to create secrets.

Analyzing Conan Doyle's stories, Shklovsky outlines aspects characteristic of the genre as a whole. These include expectations, referring to previous work, analysis; client appearance, the business part of the conversation; the introduction of clues, which are material for logical reasoning so that essential facts are not noticed by the reader; a bureaucratic (police) detective giving a false dismissal, and if there is none, the newspapers do so; unexpected untangling; detective data analysis.

The most significant and influential work which sought to describe the grammar of detective syntax is the 1966 study by Tzvetan Todorov, "Typology of Detective Fiction", (Todorov 1987, 42-52). Like Shklovsky, Todorov believes that the basic feature of detective stories is a time-shift, i.e. the fact that an incident has already taken place, which begins to unravel its nature and the circumstances under which it had occurred. He distinguishes between a whodunit, hard-boiled thriller, and suspense novel, pointing out that the evolution of the genre has passed through these stages. Each uses a different form of temporal displacement, and is delivered through two separate stories located at different narrative levels: a crime story (resting on action) and an investigation story (dealing with knowledge).

In addition, Todorov also points to verisimilitude (authenticity), which represents the reader's ability to identify the action and the overall structure of the detective genre as a typical narrative. In other words, it is a set of procedures and assumptions through which the reader sees the text as a detective. Todorov states that a whodunit rests on curiosity, and starts with the consequences (the corpse and clues) and proceeds to the cause (the perpetrator and motive), while a hard-boiled thriller rests on suspense, moving from the 
cause (the gangster gets ready for a crime) to the consequence (the realization of a plan leading to killings and fighting). This divergence of the two sub-genres relates to the theme, since a whodunit resembles a puzzle, while a hard-boiled thriller emphasizes violence, crime, and amorality.

Todorov stresses that the basis of a whodunit is duality. ${ }^{2}$ Classic detective novels contain not one but two stories: a crime story and an investigation story. The first story, the one about the crime, ends before the second begins. On the other hand, nothing particular happens, as the protagonists, the investigators, are not acting but learning. More specifically, the story of the investigation has a separate status and it is often told by a detective's friend who explicitly reveals that he is the writer of the book; the second story is based on the principle of explaining how the book was written. In this sense, the first story ignores the book completely, never acknowledging its literary nature, because the crime story tells what really happened, while the story of the investigation explains how the reader (the narrator) came to know the truth.

This distinction between the two storylines is not specific to the detective genre. These are the traits, according to Todorov, which formalists have identified as characteristic of each narrative and which pertain to the distinction between the story (fabula) and the discourse (sjuzhet): the story is what happens in life, and the discourse is the way the author presents the story.

In a whodunit, the crime story is absent but real, while the story of the investigation is present but irrelevant, as its sole purpose is to bring past events to the present. The neutral, transparent mode of storytelling further underscores the secondary role of the story of the investigation. The effect created by the reader is curiosity (which arises because the story unfolds from consequence, the body, and clues, and goes to the cause, the villain, and his motives).

A thriller (hard-boiled) vitalizes the story of the investigation by moving the crime story to another place: what happens as a private detective solves the case is primary, while the events of the past are marginalized. The crime is not reported after it has been committed, but prospection replaces retrospection, so there is no story to guess at and discover, no mystery. Contrary to the classic story, here is the effect of suspense, uncertainty, as it develops from showing the cause (the criminal, gangster preparing a crime) to the consequences (the victims, crimes).

The suspense novel has been described as the hybrid of a thriller and whodunit: the story of the investigation occupies a central place, but the events of the past have not been neglected, namely they play an equally significant role. Hence the effect is compounded: there is curiosity about what happened in the past, i.e. how these events will be explained, as well as concern (tension) about what will happen to the main character. Unlike in the whodunit, the mystery lies in the present. Todorov distinguishes

\footnotetext{
${ }^{2}$ Dichotomies are the essential structuralist methodological starting point, and it is not surprising that poetics about the detective genre is conceived upon them. For example, A. Vulis (Вулис) believes that this genre is characterized by a twofold structure: external and internal. An outside sjuzhet includes a detective and an inside criminal. The events of the inside line are hidden from the reader and reduced to the details through which the events played are assumed. These details are the clues which connect the two flows through a tangle which elucidates all the mysterious and confusing elements (Vulis 1978, 244-258). This principle of reflection is also used by Mikhail Veller (Михаил Веллер). He identifies a detective type of storytelling characterized by a "mirror" nature: one discourse line is about the murder and it is hidden but reflected through another line, a quest. Only in the end, the true truth about the front line becomes available ().
} 
between two forms of the suspense novel: the story of a vulnerable detective, as written by Hemmet and Chandler, in which the detective is often beaten, threatened, he may fall in love, and risk his life constantly. The second form is a novel about a suspected detective - a crime happens at the beginning and all the evidence points to one person (the main character) and he/she is forced to capture the perpetrator in order to prove his/her innocence. A character like this is at the same time a detective, a criminal (in the eyes of the police), and a victim (a potential target of real killers).

Although Todorov tried to provide the poetics of detective literature, the basic drawback is that his model is not dynamic, regardless of the three subgenres mentioned. The most problematic is that the same criteria, in his opinion, cannot be used for popular and artistic literature. ${ }^{3}$

Following the studies of Shklovsky and Todorov, the interest in detective stories during the 1960s and 1970s spread throughout Europe and America, and a greater number of papers appeared which, in one way or another, varied the views of these authors.

One of more significant studies is by Julian Symons (1975), who identifies eight constituent elements of the detective genre. The Events (realized through a locked room or missing verbal segment and related to forensic medicine or ballistics), a detective (amateur or professional, the central figure of the story, who notices details which went unnoticed ), the method (most often in the form of ingenious or confusing procedures), the clues (the essential elements by means of which the detective and the readers come to a solution), the characters (whereby only the detective's characterization is shown in detail, while other characters are simplified to the level of functionality in the plot and to complete expectation and recognition), a chronotope (mostly related to the time and place of the crime, that is, to the period before the crime) and the riddle (the most valuable segment of the text, because detective creations are remembered by the detective and the puzzle).

As a rule, studies from the 1960s and 1970s have described the grammar of a detective narrative by distinguishing distinctive features. Depending on which element is foregrounded, we can discern poetics which emphasize the primary properties: the plot, enigma, secret, solution, crime, and detective.

\section{The Plot in Detective FiCtion}

Wystan Hugh Auden (1988) gave the most famous, so-called "vulgar" definition of detective fiction based on the "developmental phase of the plot". According to him, the detective narrative begins with a peaceful state that is disturbed by the murder; this is followed by a phase of false leads and more murders, leading to the removal of the perpetrators from the suspect's circle. Finally, there is the arrest (or death) of the killer, an explanation of the crime, and a return to the initial peaceful state.

Auden's definition clearly indicates that the notions which bring the detective genre to action do so on the basis of distinctive discourse motives. However, there is no agreement in the literature on either the nature or the number of these motives. So, for example, back in 1931, Karel Čapek identified 8 motives which define this genre: the criminal motive, since crime is at the heart of the story; a judicial motive, because it depicts the struggle between crime and human justice; the riddle motive which establishes relations with the

\footnotetext{
3 “The same measurements do not apply to 'high' art and 'popular' art.” (Todorov 1987, 44)
} 
previous two motives; the venture motif which emphasizes that it is an epic composition which portrays an unusual individual endeavor, although detective literature is puzzlesolving. Till Eulenspiegel points to the topos of a sympathetic cunning; ${ }^{4}$ the essence of the method defines the detective as a modern man, who does not close himself off or think about himself and solve cases not instinctively, like Eulenspiegel, but methodically; the motive of the case points to the fortunate circumstances which accompany a detective and without which all reason, all method, and all universal knowledge would be futile. Bertillonage (ascertainment of identity) characterizes the detective's world as a scene of action covered in clues: a detective's reality is marked by bertillonage, it simply goes on record. The latter is the motive for uniqueness, since detective cases are criminally unique, evading all established rules, generalizations, and patterns.

Similar to Čapek, almost half a century later, George Dove $(1990,57)$ noted that detective stories consist of 7 stages: 1) - a crime alert, 2) - the start of an investigation, 3 ) - an encounter with the wrong suspect, 4) - gathering information, 5) - setting a trap to prove the detective's theory, 6) - catching the killer, and 7) - explaining the case.

On the other hand, there is a tendency to reduce the detective narrative to a smaller number of stages. For example, Lyubov Romanchuk (Романчук internet) identifies three distinctive stages of a detective story: the offense, the investigation, and the explanation.

Critics agree that the detective genre determines a coherent action and clearly achievable stages through which it develops. Such traits enabled comparisons with Aristotle and his concept of tragedy. Dorothy Sayers was the first to use the similarity in "Aristotle on Detective Fiction" (1988, 25-34), to apply Aristotle's definition of tragedy to show that action is the most important segment of detective stories: its structure has a clear beginning, middle (peripeteia, the reversal of happiness which triggers the reading) and end (a scene of suffering which rests on the discovery and possible punishment). However, unlike the tragedy, the detective does not rest in this last stage.

Geoffrey H. Hartman (1983, 211-212), who distinguishes between the Aristotelian categories of peripeteia and recognition in order to determine the characteristics of the detective genre, did something similar. Although both peripeteia and recognition are present in this genre, they are not as tightly knit as in tragedy. Peripeteia has more of an unmasking function, while recognition is free from tragic irony. That is why the author dwells on the third category of Aristotle's poetics - pathos, in terms of destructive or painful action, such as death on stage, bodily agony, wounding, etc. What is specific about the detective genre is that scenes of suffering, murder, etc. do not have to be or are not explicitly displayed, but are, like in Oedipus, behind the scenes.

But their preparation and impact are directly reflected in the scene. Peripeteia and recognition are nothing more than the means for a more powerful and clear evocation of pathos (violent scenes). Detective crime is an unusual kind of epiphany because it isolates one point in space from the usual time-space continuum. Therefore, solving a crime is nothing more than determining the exact location, not only of the killer and his motives but also of a specific place, room, ingenious or brutal circumstances, based on visible evidence. Revelations through the obvious are the basis through which "explained mysteries" are realized and supernaturally revealed as logical and explanatory. Because in the end, it turns

\footnotetext{
4 "Detective literature is the modern personification and heroization of this autonomous and practical translation." (Čapek 1967, 179, translated by D. M.)
} 
out that all the perplexing and unusual phenomena could only fit into a rational and realistic pattern.

After the 1970s, more attention was paid to the discourse, rather than the story, i.e. to the processes through which the story is transmitted, starting from the discourse, with the intention of eliciting a certain effect. For example, Donna Bennett (1979, 233-266) uses scionarrative to refer to events leading to a crime, while the events related to the very commission of the crime and its possible concealment are the core event. Mysterious motivation stems from a narrative which portrays crime as a puzzle and the detective as the one who solves the puzzle. One of the essential conditions of the mysterious narrative, according to Bennett, is fragmentary: it is a method which breaks the story into parts arranged in different places and ways in the discourse. The goal of this fragmentary approach is to discover the crime, but also to connect it all together - the purpose is to test the reader's ability to combine narrative fragments, which is rendered more difficult by the fact that the fragments are presented chronically and incompletely.

The Fragmentation is done through two basic processes: drawing attention, where the reader's interest shifts from the scionarrative to the inquiry. Another possibility is ambiguity, which means opening up different possibilities of understanding fragments by introducing new or erroneous clues. Besides fragmentation, the following essential procedures for revealing hidden narrative segments are what Bennett (Bennett 1979, 233266) calls confidence and confidentiality. Confidence is the degree to which the reader can rely on, trust in the truth of the events presented - it controls the quality of information the reader is conveyed. Confidentiality regulates the amount of information the reader and detective share. While the first procedure, once established, tends to be constant throughout the story, the second is significantly more flexible and depends largely on focalization. According to Bennett, there are five levels of confidentiality, ranging from zero (which implies that the reader is completely in the dark about what the detective knows) to almost complete, but the same level of reader and detective knowledge are never attained until the end. The reader's disclosure of the crime depends not only on the degree of confidentiality but also on how experienced he is in reading detective stories.

\section{The ENIGMA IN DETECTIVE FICTION}

The grammar of the detective genre is closely linked to the understanding that it is a genre that rests on a mystery, that is, an enigma (mysterious crime). So, John T. Irwin (1994) called the whole classic period, similar to Poe, the age of the analytical story, pointing out that the central mystery encourages the reader to duel with a detective in discovering clues to see who will solve the enigma first. Therefore, these clues must be visible and are usually hidden on the surface of the text.

Volsky (Вольский, internet) singled out the puzzle as distinctive to the genre, not the crime. Based on this, he builds a theory of detective hyperdetermination. The puzzle is what sets the detective genre apart from the rest. Even on the basis of its novelty, i.e. not to be found in the work of other authors, readers judge the quality. The detective genre rests on two basic elements without which it cannot function. The first is transgression a discourse that depicts the unraveling of a crime so that the love of this genre expresses an eternal desire (the "Western" view) or one nurtured in bourgeois society (the Marxist understanding), to violate legal and moral norms. However, the mere presence of the 
crime and its disclosure is not enough (e.g., of the 80 stories in the Sherlock Holmes collection, 5 are not based on the disclosure of the crime). This genre is often identified with police, adventure, and thrillers on the basis of an unexpected and dynamic twist, crime, involvement of the police and detectives, an atmosphere of fear and secrecy, scenes of a chase, fight, etc. Therefore, it is necessary for the crime to be related to the puzzle - if it does not or does not play a dominant role in the story (for example, if it is revealed immediately), then there is no detective story.

Volsky emphasizes that the detective's puzzle is special because it is not just the absence of information about something/someone - it is also the subtlety, i.e. it hides a series of events which lead to a concrete one - for example if a corpse is found on the street and one does not know who performed the killing and with what motive, it is not enigmatic, but if a corpse was found with a knife in its back in a locked room, then it is. The puzzle should also have a solution because, in the end, the detective has to solve everything. The riddle must be based on thought and logic, i.e. its solution must be present, but in hidden and encrypted form. If there is no solution, there is no puzzle - that is the rule of classic detective fiction.

In addition to crime and riddle-solving, detective stories, according to Volsky, must fulfill some other requirements: 1) immersion in the ordinary way of life, there must be nothing exotic because the reader would then not understand the characters, their motives, social circumstances, etc.; 2) stereotypical character behavior, they are predictable and not so much characters as social roles; the more common their motives are, the more effective they are; money is most often involved; 3) the existence of characteristic rules for the realization of sums, i.e. unwritten laws of the genre - although they are not mentioned explicitly anywhere, after reading a few of the good ones, that is, the works built on properly constructed plots, the reader intuitively knows what will happen in others. These three traits make up the hyperdeterministic world of the detective genre in relation to reality, and it is necessary to set the puzzle. In this world there is no possibility of accidental error - the detective genre is realized through two lines: one is the puzzle and everything connected with it; the second, the special "non-hinged" elements of the plot. There must be a balance between them because by overcoming the enigmatic, a pure rebus is obtained, otherwise, the detective's credibility is lost. The detective's primary weapon in this world is opinion, logic, and observation: the detective must come up with a logical method, not accidentally or intuitively, and it is clear why the world in which he moves is hyperdeterministic, of the most precise order. Because logic is only possible in such a context. The firmer the order of the world, the more successful and convincing the logic.

Michael Holquist (1983, 149-174) singled these out as the primary feature, and that the mystery revolving around the detective story refers exclusively those who convey the puzzle itself. This excludes gothic romances, psychological crime studies, or hard-boiled thrillers. The reasons and explanations for why there was no detective genre before the nineteenth century are numerous and varied, but it is obvious that there can be no detective genre without detectives, and they appeared at that time. The detective, as an instrument of pure logic, is able to triumph because he is the only one in a world of naive and gullible people who adheres to the scholastic principle of adaequatio rei et intellectus, the power of the mind over things, the belief that the mind if given enough time, can understand everything. Basically, there are no mysteries but just incorrect reasoning. 


\section{THE SECRET In DETECTIVE FiCTION}

In addition to the enigma, criticism has long been secretive about the genre's distinctive grammar feature. Nikolai Toman (Томан) states that detective narratives are those in which the method of logical analysis reveals some complex and complicated secret: the secret of criminal or political transgression, difficult to explain natural phenomena, deciphering manuscripts or historical documents, the secret of the cosmos, etc. (Томан 1960, 278).

A. G. Adamov (Аркадий Адамов, internet) thinks similarly, but more specifically. He believes that the grammar of classic detective fiction accomplishments is clear and rigorous: the detective novel is a kind of novel in which the secret of some dangerous and complicated transgression occurs as the basic material, and all summaries and all events are organized to resolve it. The offense which underlies these novels must bear a personal, private seal, and must not have anything to do with political, social, and economic reasons. As a rule, it is murder because death is the biggest taboo for a man to explain this secret means to unravel the meaning of life. That is why the effect of the detective depends not only on the subset but also on the way in which the author presents the secret, depending on his social, ideological, and ethical position.

A. A. Gozenpud (Гозенпуд, 1967, 84-111) used the motive of a secret to question established interpretations of the detective novel. It originates from the French critic R. Mesak, who defined the genre in the work "Detective Novel and the Emergence of Scientific Thought" as narratives of the gradual unraveling of mysterious events by means of reason. He also cites Boileau-Narcejac, who believe that it is a matter of exploring and explaining a secret through analysis because there is a hidden link between it and its exploration: the author creates a secret solely for the purpose of its disclosure, but also merely reveals the benefits of making it a secret. The term detective itself comes from the English word detection - exploration, revelation. ${ }^{5}$

The "evolution" of the genre also implies a change in the methods used by detectives on their way to a solution: from Holmes' magnifier, intuition and psychology emerged as the clues point to the depth of the human soul, which became the scene of the detective's and criminal's struggle. Therefore, the detective's function no longer boils down to solving the mystery. Nevertheless, new forms of the detective genre are replacing the logical and orderly world of the classical school with chaos and violence, i.e. organized crime as a typical form of capitalist society. This caused the characters of the detective and the villain to change dramatically and get closer, leaving fair play completely aside. The detective genre in this form is a thriller in which everything is based on the gross effect and the desire to shake and scare the reader. Interestingly, Gozenpud puts parodies side by side with literal detective creations and speaks of them as forms which enrich the genre.

Vulis (Вулис 1986, 254-279) offered a genre theory which rests entirely on secrecy. He finds the detective genre unique in that it is completely identical to the mystery. Based on the relationship between mystery and composition, Vulis distinguishes between two types: one in which the offender is known and one in which he is unknown. And the secret of detectives, especially the classic ones, is twofold: at first, it represents some faroff hidden thing. But in the end, it turns out that the mechanism of his disclosure has always been present, from the very beginning. The basic element of this mechanism is the trace, characterized by its threefold relation to the past, present, and future. The villain

${ }^{5}$ Cf. Jacques Barzun and W. H. Taylor: “A detective story should be mainly occupied with detecting.” (Barzun, Taylor 1971, 5) 
leaves him in the present, revealing to the detective the past and pointing to the future, i.e. the discovery of the perpetrator. The secret is unevenly distributed: it is fully understood by the author, not the narrator: the more the former knows, the less the latter.

Vulis points out that the search for a solution to the mystery involves two types of detectives. The first covers the range from the intuitive-artistic (Holms, Poirot, etc.), to a journalist on vacation. The other is more scientific, and the focus is on an inspector with police service. A traditional detective scheme is usually based on the following: first, a mystery emerges as a depersonalized fact or event; in the second phase it is personalized, then becomes complete and a whole ensemble associated with it occurs, but it is not known how, actively (perpetrators, witnesses, participants, victims) or passively (falsely accused, accidentally involved). In the third stage, there is a false division of roles achieved through character testing and misconceptions. The fourth is the movement from the first impression (reception) to the main event, and it realizes the dialectics of the event and the possible finale. The fifth stage is a complement to the personification of the mystery: a new hero enters the scene and through retrospection presents a different perspective. The last stage focuses on unraveling the mystery like the relationship between the characters and it becomes a memory of the collective dreams of authors, characters, and readers.

A somewhat different definition of detective fiction and its connection to the secret was given by Mihalko Skalicki (Мыхалко Скалицки, internet). According to him, the detective narrative is no secret in the sense that it depicts the disclosure of a crime, the intentions, and the motives. The subject of the detective narrative is a secret crime and an activity - an investigation - which turns into a public crime. Public crimes differ from covert ones in that they are determined by witnesses and clues which unambiguously and infallibly associate the crime with the criminal, the man with the act. Witnesses and clues are verified by the court, at least by the reader, and the elementary search procedures are examination and analysis. The perpetrator is always discovered, so the crime of the detective is never mysterious. Skalicki insists that the mystery of this genre concerns only the initial situation when the perpetrator is unknown, but witnesses, clues and ultimately discovery make it impossible to declare the detective narrative as such in its entirety.

Glenn W. Most (1983, 341-365) associates the mystery of the genre not with crime but with the detective. She believes that the real mystery in a mystery novel is not related to the crime committed at the beginning and resolved at the end, but rather that the problem depends on the personality of the detective. Crime is always mysterious, either for its bizarreness or simplicity, and the plot of the novel ranges from a lack of answers to the puzzle, through a series of wrong answers, to the final true answer. The essence of the genre is that this response causes the reader to wonder how he could not have come to the same conclusions. Although murder, the most common crime in the detective genre, is mysterious, the biggest mystery is the detective himself, especially the things he does between two incidents. In any case, he is a marginal figure: his profession is to examine the affairs of others, he is able to move through all walks of life, though in no sense does he feel it like his own; he is mostly single, unmarried or divorced, his parents are never mentioned and he is irreparably childish.

\section{THE SOLUtion In DETECTIVE FICTION}

A considerable number of works imply that the solution is the most important for the detective genre and that all other characteristics are built on it. Julian Symons (1975) states 
that for most critics, the detective genre is singled out as central and the one based on which other crime stories and thrillers make variations. Therefore, they sought to set strict rules about what is and what is not a detective story. In this sense, two characteristics are imposed as necessary. The first is that there is a problem, and the second is that it has to be solved by an amateur or professional detective through the deduction process.

Roger Caillois (1983, 1-12) emphasizes that although the detective asks himself the usual questions: Who? When? Where? Why? They are not of equal importance to the story. The most important is How? because it rarely happens that a murder is committed in ordinary, non-mysterious circumstances; it is always enigmatic. The author's ingenuity is reflected in the realization of such circumstances and their solution in the end as unexpected and simple. Thus, the pleasure one gets from reading is not in the story itself but in the illusion which the author creates. In order to determine the time and place of the crime, the manner in which it was committed, the motive and identity of the killer, consciously or unconsciously, certain rules are followed: the separation of a particular group of people from the surrounding world so that no one can leave or come; the absence of simple solutions using the deus ex machina procedure; the facts behind the mystery are the principles on which the mystery is built. Detective fiction is therefore not a game, but a problem which must be solved.

Stefano Tani (1984) summarizes the conventional detective story definitions of a fictional narrative in which an amateur or professional detective tries to rationally solve a mysterious event - mostly crime, usually murder. This definition rests on three elements: the detective, detection, and solution. Their order is distinctly chronological, and any disturbance of that order causes the whole sequence to be altered or undermined. Other than these basic features, there is the explanation of crime-mysteries, suspense (interaction between detection and solution, and their play with the expectation of the reader), and the delay in the solution (usually caused by a mistake).

Tani believes that the solution is the most important element because it is the last and roundest connection to the remaining sequences, part of which confirms and realizes genre identity and meaning (Tani 1984, 41). It is curious that contrary to the usual sense of discovery, and the scientific first and foremost, there is a detective turned to the past. This means that the detective uses scientific methods, but his discovery is from the past, archeological.

Stefania Ciocia (internet) looks at the so-called metaphysical, metafictional, or antidetective literature and its position in the history of this genre within the ideological interpretation of the solution. The prefixes anti-, metaphysical or meta-fictional, indicate how contemporary authors have managed to unify the post-modernistic loss of end and completeness, as well as the lack of solid, secure ontological categories by a literary formula which has traditionally been based on solution-conclusion and logical interpretation of reality, and provided answers regarding the problem of order and order disruption in the form of an explanatory end. These prefixes indicate a modification of the detective formula and a shift from epistemological (whodunit) to ontological concepts. In the postmodern literature, there is a revision of the detective genre in terms of replacing epistemological aspirations with questions related to the post cognitive.

Ciocia states that each period, i.e. the detective school has a different (ideological) attitude toward the solution. In classical detective fiction, there was an ideology which rested on the belief in the detective's epistemological powers. Detection was presented as an elite, moral, and conservative intellectual game. The detective relied on a rational and 
contemplative approach to the case, remaining completely emotionally distant from it, with no personal interest. The ultimate goal of the game is to return, not to re-examine the status quo, whose ideology a priori is not questioned.

The postmodern antidetective fiction emphasizes the significance and effect of the detective's hermeneutic act through a provocative lack (or suspension, or parody) of the solution. Postmodern detectives apply hard-boiled epistemological and moral skepticism to the literary medium itself. To show this, Stefania Ciocia uses Bart's picture from "The Literature of Exhaustion", in which Dariasada realizes that the key to the treasure is the treasure itself. In this sense, the solution in the postmodern detective genre is not achieved by connecting pieces of the puzzle, but through imagination. Calvino calls it a mental model through which events are lived, that is, a mental model through which events are ascribed meaning (Calvino 2001, 141). The act of detection becomes an act of invention, both in the epistemological sense of retrieval as well as in the sense of ex novo: the task of the detective/writer is not to reconstruct the existing order. On the contrary, he has to let reality pass through his own narrative filters which make life understandable and therefore possible to live.

\section{THE CRIME IN DETECTIVE FICTION}

Interestingly, although the detective genre has something to do with crime, it is never viewed separately, but always in the context of a mystery and/or solution. Also, almost everyone agrees that homicide is primary among other crimes. For example, Lyubov Romanchuk believes that the detective genre depicts the process of exposing a crime. Ernest Bloch (1970, 421-426) singled out the development of the judiciary as essential to the emergence of the detective genre: before the introduction of indications, it was tried "by feel" or by duress. It was only with the inclusion of the judiciary which insisted on proper procedure that the arrest warrant and the court proceedings were created. Therefore, even an account of the detective's work on indications cannot be older than the indicative procedure.

According to Bloch, the features of the detective genre are threefold. First, there is the tension of the prosecution. The second is uncovering, discovering, and the third deals with events which need to be extracted from the untold event, the one before the story. The last feature is most characteristic of detective fiction and is exceptional, even more so than the character of the detective - before the first chapter, before the first word of the text, something happened and is to be sought and to be discovered, but no one, not even the narrator, knows what. The crime took place outside the text and should be reported through the text - that presentation is also the main theme of the detective genre. Although built on blood and corpses, these attractions do not really matter to a good detective story. They just cause a purely intellectual effort, figuring out who the perpetrator is. A forensic amateur is often a bohemian, unemployed and lives in leisure, but what catches his eye is what no one notices according to habit or scheme. Aside from being talkative, the detective also has another trait which is characteristic of lawyers - suspicion.

Jerry McCoy (2003) states that (classic) detective fiction is mostly housed in a segregated setting (e.g., rural England) and includes a small number of characters. Crime is usually murder because it is considered to be worthy of the representation and length awarded in a novel. The detective holds the central position, and through examining and studying clues as well as reasoning ability, solves the mystery. During this process, a large 
number of wrong clues and episodes emerge and almost all the characters have some secret which they try to hide, as well as a reason for killing. The detective is forced to sort out the clues, dismiss the irrelevant ones, and dwell on the significant ones. During this, the character who eventually turns out to be innocent initially acts as the culprit. If the author plays by the "rules", the solution will be logical and probably based on the clues shown throughout the text. It is always delivered through dramatic speech which assures the listeners (characters) of the detective's proper explanation of the necessary, real clues.

\section{The DeteCtive IN DETECTIVE FiCTION}

From the beginning of detective fiction, the detective has been singled out as a distinctive figure of the genre. As part of his basic background, the first authors-critics (Chesterton, Van Dine, etc.) cited intellectual (and scientific) abilities. Although he did not stand out in anything (Sayers spoke of the tendency of producing detectives striking only in their ordinary ways), Holmes' eccentricity was taken as the dominant characteristic.

Helmut Heissenbüttel (1983, 79-92) states that there are two striking pairs of detectives: one who firmly, even brutally breaks his opponents, occasionally being beaten up until he finds the perpetrator, and the other who, through fact-finding and combinatorial puzzlesolving, turns what at first seems confusing and difficult to understand into something logical and understandable. But the difference between logicians and violent detectives is only apparent and not so pronounced since one method does not excludes the other. Basically, the detective genre is a variation of a single story. All the "realistic" elements in these stories, such as psychological, economic, or social characteristics, are organized to fit a game matrix which can be encoded and decoded. Molding is accomplished through two procedures: reduction and abnormality. In the first case, motives and characters are not examined, but the action is played by a pattern, while the second involves the introduction of strange and bizarre characters or motifs, as is the case with the orangutan from Poe's "The Murders in the Rue Morgue".

Keszthelyi (Кёстхейи 1989, 56-97) offered the following classification of detectives: a puzzle detective (Doyle), a historical detective (John D. Carr), a social detective (D. Sayers), a police story (Edgar Wallace), a realistic (E. S. Gardner), naturalistic (Dashiell Hammett), or literary one (Georges Simenon). Bavin (Бавин 1991, 93) added a (super) intellectual detective to this, and Romanchuk (internet) completed the list by introducing: scientific (O. Friman, F. Krofts), intuitive (G. Chesterton, A. Christie), delinquent detectives (Arsen Lupen, M. Leblanc), black novel detectives and metaphysical detectives. ${ }^{6}$

René Dietrich (internet) uses Lacanian discourse also based on the figure of the investigator, i.e. the relationship between the self and the other, and distinguishes between detective fiction and postmodern noir. The author considers noir a modernist form which portrays the world of shaken moral values and the researcher as the only one who can restore integrity. In the postmodern noir, such a position is abandoned, and a complete disintegration is shown. The difference between these two forms is primarily connected to identity. To prove this, Dietrich distinguishes three types of investigators: the stable, lost, and duplicate.

\footnotetext{
${ }^{6}$ In his extensive bibliography, Allen J. Hubin distinguishes between 6 types of serial characters: the adventurer, amateur, criminal, police officer, private detective and spy (Hubin 1984).
} 
The stable investigator dominates the modernist noir, with Spade and Marlowe as characteristic representatives, while the lost and the duplicate occur in the postmodern. In contrast to modernist investigators who are wholly free and independent, postmodernism has shown a lack of control and integrity from the beginning. They are lost both in terms of the lack of some internal principle to rely on, i.e. they are lost in themselves, and in terms of disorientation in the outside world. Investigators in the postmodern are haunted by their past and, in an attempt to break free of addiction and connection to it, portray the usual illusion that one can escape from the past. As the hero brings his whole self into the investigation, the lost investigators are doomed to misinterpret events, lose control of the narrative, and endanger their own identity through corruption and self-deception. In the general neutralization of the dichotomy in the postmodern noir, the shift towards an unstable investigator identity leads to the disappearance of the usual opposition between the investigator and the object of investigation, whether it is a planned-out crime or a missing person. For a lost investigator, this means losing one's identity through identification with the criminal or missing person, or leads to a role reversal when the detective becomes a criminal or missing person.

A duplicate (split) investigator radicalizes the state of the lost. Not only does he lack a complete control and stability from the beginning, but every concept he has about his own integrity proves to be an illusion. More than being persecuted by the fallacies and mistakes of the past, his entire existence is corruption and deception. The failure of the investigation leads him to a state which shows how every concept of identity and self-awareness disintegrates into nothing. The misinterpretations which condition the loss of control over the narrative are based not only on the wrong judgments of what is happening around him but on the misconceptions of one's own existence. The investigator's illusions can be linked to the split of his personality, the fragmentation of identity. He is not fully aware of this split, but in the end, he inevitably faces it. In the wake of the postmodernist state of collapse of the opposition, the split investigator becomes the object of self-inquiry. That is why two classic opposites come together in one person. In the end, either side wins or they neutralize each other. The fragmentation of the character and his status can be linked both to the unsuccessful attempt to reconcile with the past, and can also be used to disclose the pervasive false narratives and evil aspects of self-deception.

\section{CONCLUSION}

Formalist-structuralist grammars take into account actants, i.e. central elements of the detective genre syntax: the plot, enigma, mystery, solution, crime, detective. These elements are viewed as interdependent - due to the relationships they establish in the text. The role of the reader and the context has only been mentioned and everything stems from and comes down to the detective. Turning to the discourse - contextual and cognitive aspects of the detective genre will bring post-structuralism and post-classical narratology, which will complete the aforementioned research and open the way to new domains: phylogenetic (gender, racial, colonial) and ontogenetic (mental and emotional). 


\section{REFERENCES}

Auden, W. H. 1988. "The Guilty Vicarage". Detective Fiction: A Collection of Critical Essays. Ed. Robin W. Winks. Woodstock: Countryman Press.

Barzun, Jacques. Taylor, W. H. 1971. A Catalogue of Crime/Being a Reader's Guide to the Literature of Mystery, Detection, and Related Genres, New York: Harper \& Row.

Bennett, Donna. 1979. "The Detective Story: Towards a Definition of Genre". PTL: A Journal for Descriptive Poetics and the Theory of Literature, 4: 233-266.

Bloch, Ernest. 1970. "Filozofski aspekt detektivskog romana". Mogućnosti. Split: 421-426.

Boileau - Narcejac. 1964. Le roman policier, Paris: Payot.

Caillois, Roger. 1941. Le Roman policier. Paris: Éditions des lettres françaises.

Caillois, Roger. 1983. "The Detective Novel as Game". The Poetics of Murder. Detective Fiction and Literary Theory. Eds. Glenn W. Most and William W. Stowe. San Diego, New York, London: Harcourt Brace Jovanovich: 1-12.

Čapek, Karel. 1967. Marsija, ili na marginama literature. Beograd: Kultura.

Ciocia, Stefania. 2005. "Write to Kill: The Death of the Author in Contemporary Anti-Detective Fiction". The Twenty-First Century Novel: Reading and Writing Contemporary Fiction. Lancaster University Conference 23 Sept: http://www.lancs.ac.uk/depts/english/21st-century/s_ciocia.htm

Dietrich, René. Postmodern Noir Investigations and Disintegrations of Identity. Freiburg. http://www.crimeculture. com/Contents/Articles-Summer05/ReneDietrich.html

Dove, George. 1990. "The Detection Formula and the Act of Reading". The Cunning Craft: Original Essays on Detective Fiction and Contemporary Literary Theory. Ed. Ronald G. Walker and June M. Frazer. Illinois: Western Illinois University Press.

Fosca, François. 1937. Histoire et Technique du Roman Policier. Paris: Éditions de la Nouvelle revue critique.

Hartman, Geoffrey H.1983. "Literature High and Low: The Case of the Mystery Story". The Poetics of Murder. Detective Fiction and Literary Theory. Eds. Glenn W. Most and William W. Stowe, San Diego, New York, London: Harcourt Brace Jovanovich.

Heissenbüttel, Helmut. 1983. "Rules of the Game of the Crime Novel". The Poetics of Murder. Detective Fiction and Literary Theory. Eds. Glenn W. Most and William W. Stowe. San Diego, New York, London: Harcourt Brace Jovanovich: 79-92.

Holquist, Michael. 1983. "Whodunit and Other Questions: Metaphysical Detective Stories in Post-War Fiction". The Poetics of Murder. Detective Fiction and Literary Theory. Eds. Glenn W. Most and William W. Stowe. San Diego, New York, London: Harcourt Brace Jovanovich: 149-174.

Hoveyda, Fereydoun. 1956. Petite histoire du roman policier, Paris: Editions du Pavillon.

Hubin, Allen J. 1984. Crime Fiction 1749-1980, A Comprehensive Bibliography. New York: Garland.

Irwin, John T. 1994. The Mystery to a Solution: Poe, Borges, and the Analytic Detective Story. Baltimore and London: JHU Press.

Kalvino, Italo. 2001. Ako jedne zimske noći neki putnik... Prevod Ana Srbinović. Beograd: Plato.

McCoy, Jerry. 2003. "Detective and the bible: Biblical themes in mystery fiction". The Encounter. Indianapolis, 64, 1: 75-94.

Most, Glenn W. 1983. "The Hippocratic Smile: John le Carre and the Traditions of the Detective Novel". The Poetics of Murder. Detective Fiction and Literary Theory. Eds. Glenn W. Most and William W. Stowe. San Diego, New York, London: Harcourt Brace Jovanovich: 341-365.

Narcejac, Thomas. 1947. Esthétique du roman policier, Paris: Le Portulan.

Sayers, Dorothy. 1988. "Aristotle on Detective Fiction". Detective Fiction: A Collection of Critical Essays. Ed. Robin W. Winks. Woodstock: Countryman Press: 25-34.

Siewierski, Jerzy. 1979. Powiesc kryminalna. Warszawa: Krajowa Agencja Wydawnicza.

Symons, Julian. 1975. Bloody Murder, From the Detective Story to the Crime Novel: A History. New York: Mysterious Press.

Tani, Stefano. 1984. The Doomed Detective. The Contribution of the Detective Novel to Postmodern American and Italian Fiction. Southern Illinois University Press.

Todorov, Tzvetan. 1987. The Poetics of Prose, New York: Cornell University Press.

Адамов, Аркадий. «Разговор на берегу, Открытия и загадки Эдгара По, Мой любимый жанр - детектив». Классический детектив: поэтика жанра: http://detective.gumer.info/text.html

Бавин, С. 1991. Зарубежный детектив ХХ века, Москва: Книжная палата.

Веллер, Михаил. «Композиция». Технология рассказа: $\mathrm{http}: / /$ www.weller.ru/text/tech_r/g3.shtml.htm

Вольский, Николай. «Загадочная логика. Детектив как модель диалектического мышления“. Классический детектив: поэтика жанра: $\mathrm{http}: / /$ detective.gumer.info/text.html.

Вулис, Абрам Зиновьевич. 1978. «Поэтика детектива». Новый мир: 244-258.

Вулис, Абрам. 1986. "Типология приключений". В мире приключений. Поэтика жсанра. Москва: 254-279. 
Гозенпуд, Абрам Акимович. 1967. "Детективная драма". Пути и перепутья. Английская и франиузская драматургия ХХ века. Ленинград: 84-111.

Кёстхейи, Т. 1989. Анатомия детектива. Будапешт: Корвина.

Нудельман, Рафаил. 1972. "Детективная литература". Больиая Советская энииклопедия, Классический детектив: поэтика жанра: http://detective.gumer.info/text.html

Романчук, Любовь. Новеллистический ичикл Честертона, www.roman-chuk.narod.ru/1/Chesterton.htm

Скалицки, Мыхалко. Феномен детектива, $K$ вопросу о своеобразии детективного повествования: http://literra.websib.ru/volsky/text.htm?505

Томан, Николай. 1960. "Что такое детективный роман", О фантастике и приключениях. Ленинград.

Чуковский, Корней. 1959. "Предисловие", А. К. Дойл, Записки о Шерлоке Холмсе. Алма-Ата.

Шкловский, Виктор. 1929. О теории прозы, Москва: Ардис.

\section{GRAMATIKA DETEKTIVIKE}

U ovom radu bavimo se sintaksom, odnosno gramatikom detektivskog žanra. Naglašavanjem pojma gramatike ističemo da je reč o poetikama formalista i strukturalista koji su smatrali da svaka detektivska priča predstavlja deo jedne veće apstraktne strukture i kao svoj osnovni zadatak uzimali su opisivanje te strukture nastojeći da dođu do gramatike detektivskog narativa. „, Glavni junak” proučavanja jeste zaplet (siže) koji je izdvajan kao pogodan za eksplikaciju opštih principa po kojima narativi funkcionišu. S obzirom na to da su formalističko-strukturalističke gramatike u fokus uzimale aktante, $t$ j. centralne elemente sintakse detektivskog žanra, rad je baziran na prikazu najznačajnijih poetoloških uvida o fabuli (zapletu), enigmi, tajni, rešenju, zločinu i detektivu. Ovi elementi posmatraju se u međusobnoj zavisnosti - odnosima koje uspostavljaju u tekstu. Uloga čitaoca i konteksta samo je pomenuta i sve proizilazi i svodi se na detektiva. Definisanje gramatike detektivskog žanra omogućilo je okretanje diskursnim - kontekstualnim i kognitivnim - aspektima u poststrukturalizmu i postklasičnoj naratologiji što će upotpuniti pomenuta istraživanja i otvoriti put ka novim domenima: filogenetskim (rodnim, rasnim, kolonijalnim) i ontogenetskim (mentalnim i emotivnim).

Ključne reči: zaplet, enigma, tajna, rešenje, zločin, detektiv 